\title{
INDIGENOUS AGENCY AND MINERAL DEVELOPMENT: A CAUTIONARY NOTE Catherine Howlett
}

It is necessary to understand that the present conjuncture, far from being the only natural or possible societal order, is the expression of a certain configuration of power relations. It is the result of hegemonic moves on the part of specific social forces that have been able to implement a profound transformation in the relations between capitalist corporations and the state.

Ernesto Laclau and Chantal Mouffe ${ }^{1}$

Introduction Across the world, Indigenous peoples, encapsulated within a variety of political systems and embracing a diversity of cultures, share a common material reality. People who are Indigenous are much more likely to be economically disadvantaged than their non-Indigenous counterparts. ${ }^{2}$ Social and economic indicators from around the world confirm the high rates of poverty, unemployment, poor educational outcomes, ill health, family violence, and high rates of suicide and incarceration that are prominent in Indigenous communities. ${ }^{3}$ Indigenous peoples represent the most socially and economically marginalized populations around the globe. ${ }^{4}$ In Australia, Indigenous people are recognized as the most disadvantaged group within Australian society.

Resource development, with its potential for opportunities such as employment and training, is often presented as a panacea for some of the problems facing Indigenous communities. ${ }^{5}$ In Australia, mineral development is seen as a mechanism whereby Indigenous people living in remote regions may enter into the capitalist economy. It is argued that the benefits created by large-scale mining projects could help overcome the disadvantage that currently characterizes Aboriginal Australia. ${ }^{6}$ The negotiating period, 
where Indigenous people are legislatively ensured a right to negotiate with the state and mineral development companies, is a critical point in the mineral development process, where Indigenous people can exercise their agency to maximize the benefits and minimize the impacts they obtain.

Prior to the High Court's Mabo decision in 1992, Indigenous Australians held a weak and tenuous bargaining position in many mineral negotiation processes, with legislative protection of their interests usually based upon relevant State government heritage protection legislation. An exception was the Northern Territory, where Indigenous Australians held the right to veto mining projects on their traditional lands via rights afforded them under the Aboriginal Land Rights (Northern Territory) Act 1976 (ALRA (NT)), which gave them a very strong bargaining position in mineral negotiations. The Mabo decision wrought significant structural changes to the landscape of Indigenous rights and presented a challenge to the existing Australian system of property rights. The legislative response to the Mabo decision, the Native Title Act 1993 (NTA), created a potential space to facilitate Indigenous agency and a strengthening of their bargaining position via the Right to Negotiate (RTN) procedure of the Act. Since the Mabo decision, Aboriginal peoples in Australia have been increasingly involved in negotiating terms for large-scale resource development on their traditional lands. ${ }^{7}$

States play a key role in the definition and control of resources. ${ }^{8}$ They establish property rights, enforce commercial contracts, and regulate the behaviour of the private sector in areas such as company and environmental law. ${ }^{9}$ States define the terms on which resources will be accessed, produced, transported, and marketed. ${ }^{10}$ In short, states shape the institutional framework within which resource development occurs, and, as such, are a major determinant of the constraints and opportunities faced by the various actors involved in resource development. ${ }^{11}$ In Australia, due to the federal nature of the Australian polity, several arms of the state are involved in determining the terms and conditions under which mineral development occurs, including Federal, State, and Territory governments, the judiciary, and various other statutory bodies and agencies. Under the principle of crown ownership, Australia's State governments can claim an interest in almost all subsurface minerals, which entails the rights to allocate exploration and 
mining titles, and to require various fees and royalty payments. ${ }^{12}$ The Australian state is thus a key player in mineral development and its behaviour has enormous significance for determining the negotiating environment in which mineral development takes place.

There is a perception that the state often plays a negative or deleterious role in mineral negotiations involving Indigenous peoples. Indeed, the literature on Indigenous peoples and mineral development in Australia is replete with case studies of mineral developments in which Indigenous Australians were marginalized, both in the decisionmaking process and from the potential benefits accruing from resource developments on their traditional lands. ${ }^{13}$ This resonates with the view of many Indigenous people who see unwillingness by many governments and state agencies to uphold their rights (even when these are recognized in national and international law) and a reluctance to distribute financial benefits that accrue from mining to their communities. ${ }^{14}$ Given that mining can often represent the only opportunity that Indigenous peoples living in remote regions have to generate independent wealth and participate equitably in the broader capitalist economy, ${ }^{15}$ mineral development negotiations offer a unique opportunity to analyze the efficacy of Indigenous agency in the face of state developmental agendas.

There has been a notable tendency of late, in both the national and international literature, to celebrate the many victories achieved by Indigenous peoples worldwide in the face of development projects on their traditional lands. ${ }^{16}$ This trend attributes these victories, in part, to the transformative capacity of Indigenous agency. However, a central contention of this paper is that this tendency to focus on the transformative capacity of Indigenous agency carries with it the inherent danger of "taking our eye off the ball" and ignoring the omniscient reality of the structural relationship between the state and capital that informs state developmental agendas, and sees Indigenous aspirants continually marginalized in resource development processes on their traditional lands.

This paper presents this argument, drawn from doctoral research carried out between 2001-2004, within a broader discussion on the relationship between structure and agency-a discussion that has troubled political and social scientists for some time and has been claimed "to be the most 
important theoretical issue within the social sciences." 17 Ruminating on this theoretical issue is critical for the purposes of this paper, as any claims for advocating caution in relation to overstating the transformative capacity of Indigenous agency must be situated within current developments in the theoretical literature. This paper does not attempt to adjudicate on the debate, nor make a case for the primacy of either structure or agency. Rather, it seeks to distill the major insights from that debate and use these as a framework for the ensuing analysis of the Century Mineral negotiations from the Gulf of Carpentaria, Northern Australia, negotiations that occurred during a transformative period in relationships between Indigenous Australians and the Australian state.

The argument is presented in three main sections. The first section outlines the contours of the debate regarding structure and agency within political science. The second section presents both an overview of the case study of mineral negotiations in the Gulf of Carpentaria, Northern Australia, "the Century Zinc Mineral negotiations," and an analysis of the findings from the case study in light of the central tenets of the debate on structure and agency. This analysis highlights that while Indigenous agency proved a critical factor that influenced the outcomes of these negotiations, this same agency was inhibited and constrained by the structural reality of the historical and institutional relationship between the state, capital, and Indigenous people in relation to mineral development. Extrapolating from this analysis, the conclusion argues for caution when advocating the transformative power of Indigenous agency.

The Structure and Agency Debate All political theories make reference to either the causal powers of groups (agency), or contextual factors such as the environment, or patriarchy, or capitalism (structures).$^{18}$ Hay contends that the question of structure and agency goes to the heart of what it means to provide an adequate explanation of social phenomena. ${ }^{19}$ Lewis concurs, arguing that in order to understand and explain social phenomena it is essential to examine the interaction between structure and agency, for all social life issues from this interaction. ${ }^{20}$ While, historically, sociologists have focused on the examination of structure and agency, there has been 
a recent refocusing on these issues within political science. ${ }^{21}$

At this point, it is requisite to provide definitions of the central terms in the debate: structure and agency. Structure, according to Hay, refers to context, to the material conditions or setting in which social, political, and economic activity occurs and that define the range of actions available to actors within a given policy domain. ${ }^{22}$ Structure refers to the enduring, though not immutable, circumstances within which actors operate, or, similarly, "the conditions of action." 23 While political institutions and practices, routines and conventions, appear to exhibit regularity or structure over time, and are, in fact, structured contexts, they are not structured in a determined or predictable sense; this is because of agency. ${ }^{24}$ Agency refers to an individual's or group's ability to affect their environment with their political conduct, or, similarly, their ability or capacity to act consciously to realize their intentions. ${ }^{25}$ This notion of agency implies a sense of free will, choice, or autonomy for political actors, with an implicit inference of conscious deliberation. Agency centred or agential explanations thus emphasize the conduct of the actors directly involved, implying that it is their behaviour, their agency that is responsible for the effects and outcomes we observe. ${ }^{26}$

The structure/agency debate addresses the critical relationship between political actors and the environment in which they find themselves, the extent to which political conduct shapes, and is shaped by, political context. The debate gained prominence in Europe with the adoption of the Third Way as a policy framework in post-Thatcherist Britain. With its emphasis on transformation of values, The Third Way advocated a significant role for political agency as an enabling, transformative resource. ${ }^{27}$ There has tended to be an ontological divide operating between structural and agential explanations of political phenomena, with either side arguing for the primacy of its side in explaining political outcomes. Giddens' structuration theory was an attempt to transcend the debate on structure and agency via development of a hybrid theory that recognized their mutual dependence. ${ }^{28}$ For Giddens, structure and agency are ontologically fused; they are, in fact, "two sides of the same coin" that may be separated only analytically. ${ }^{29}$ Giddens thus conceives of structure and agency as mutually constitutive; they are a duality as opposed to a dualism and, in this perspec- 
tive, it is possible to view only one at a time because they are distinct entities that exist only in relation to each other. ${ }^{30}$

Similarly, Hay also conceptualizes structure and agency as ontologically inseparable: "neither has an existence in isolation from the other, their existence is relational." For Hay, the only distinction between structure and agency is an analytical one: neither structures nor agents are real, as neither has an existence in isolation from the other. Therefore, their relationship is dialectical because their interaction is not reducible to the sum of structural and agential factors treated separately. Hay insists that political analysis needs to focus on this dialectical interplay of structure and agency, rather than on any reification or privileging of either one. ${ }^{31}$

Archer argues that these perspectives conflate structure and agency. She contends that, in reality, structure and agency are ontologically distinct entities with different properties and powers. ${ }^{32}$ Archer, a critical realist, argues that we should be more concerned with how structure shapes interaction, and interaction, in turn, reshapes structure, that we must differentiate the two and not conflate them, so we can analyze their interplay. For Archer and other critical realists, structurally emergent properties, though dependent on the actions of agents, are real and causally efficacious, and can, therefore, impinge upon agents by generically shaping the situations that they confront. ${ }^{33}$ While this structural power is not always observable and not able to be accounted for empirically, it does exist and it does affect agency.

Critical realists thus do not reject the dialectical relationship between structure and agency. Lewis contends that they are "recursively related": each is both a condition for, and a consequence of, the other, and neither can be reduced to the other. Critical realists insist, however, on a temporal relationship between the two, as all social activity (agency) takes place within contexts that are provided by a pre-existing set of social structures. It is worth quoting from Lewis on this point:

Social structures exert causal influence over the behaviour of actors because at any given point in time antecedent social structures embody a particular distribution of vested interests and resources. ${ }^{34}$ 
This approach contends, therefore, that history matters, and the historical distribution of resources and interests laid down structurally over time may exert an important enabling or constraining influence on agency.

As stated earlier, this paper does not aim to adjudicate on the structure/agency debate, or to make a definitive claim for the primacy of either. The aim is to advocate caution against overstating the transformative capacity of agency. Thus, it is prudent to distill the central insights from the preceding discussion to get a comprehensive picture of the importance of both structure and agency, and the critical relationship between them. These insights can be summarized as follows: structure and agency are dialectically linkedstructure effects agency, and agency in turn influences structure; all agency occurs within prestructured contexts; structurally emergent properties, though dependent on the actions of agents, are real and causally efficacious; and finally, history matters and the historical distribution of resources and interests laid down structurally over time may exert an important enabling or constraining influence on agency. What follows is an overview of the negotiation process for the development of Century Zinc mine, with these insights in mind.

The Century Mine Negotiations The Century negotiations occurred in a transformative period in Australian history. The legislative and institutional frameworks governing the relationship between mineral development and Indigenous people were altered significantly when the High Court handed down the historic Mabo decision, which recognized that Indigenous people had land rights that preceded the 1788 acquisition of sovereignty by the British. This was also a period in which the Australian state was facilitating the globalization of the Australian economy by adopting neoliberal policies. In this context, the significance of a project the size of the proposed Century mine was clear. Century offered the prospect of economic growth and employment opportunities that had, up until this stage, bypassed the Gulf of Carpentaria. Century was expected to become one of the largest zinc producers in the world and to contribute substantially to Queensland's economic growth. The government saw Century as signalling the start of a major resources boom in what had been, for many decades, an economically 
depressed region of the state. ${ }^{35}$ The Century negotiations became a test case for the workability of the RTN procedure and the focal point for the whole native title debate at the time.

The Century Mine is a zinc/lead mine located in Far North West Queensland, $250 \mathrm{~km}$ northwest of the regional centre of Mt Isa and $150 \mathrm{~km}$ from the Gulf of Carpentaria. The mine itself is located on Lawn Hill pastoral lease, approximately $100 \mathrm{~km}$ from the Aboriginal community of Doomadgee. It was intended that the mineral concentrate from the mine would be conveyed in slurry form, via an underground pipeline, $300 \mathrm{~km}$ to the port of Karumba in the Gulf of Carpentaria, from where it would be barged to ships further out in deeper Gulf waters. ${ }^{36}$ The project affected a wide range of Aboriginal people in the region, including coastal and island communities that could have been affected by any adverse environmental impacts associated with the loading and transhipment of concentrates. The Gulf of Carpentaria is a remote monsoonal region subject to seasonal cyclones. It has poor road access, limited infrastructure, and high unemployment. The region was, in the words of the then-Queensland Premier, "an economic basket case-it was like going to some long lost frontier, some outpost in the wilderness." ${ }^{37}$

The region contains two predominantly Aboriginal towns: Doomadgee and Mornington Island. Burketown and Normanton are small remote townships in the region that serve as service centres for local council governance. Both towns have large Aboriginal populations. ${ }^{38} \mathrm{Mt}$ Isa is the major regional service centre. Century Mine was seen as a major economic boon to the area, with officials estimating $\$ 429$ million in annual output and a total of 1,340 jobs for the region, making the mine the largest single economic activity in the southern Gulf. ${ }^{39}$

The Gulf is one of the most sparsely populated regions in all of Queensland. The economic and cultural characteristics of the Gulf Aboriginal population were of major significance for the negotiating environment. ${ }^{40}$ In the early 1990s, the Mt Isa region had an Aboriginal population of approximately 6,000 people, whose life expectancy ranked among the lowest of all Queensland regions. Sanitation and water supply were inadequate or nonexistent, and there was an acute shortage of housing. Aboriginal people 
in the region had the lowest educational qualification rates of any Queensland region. Murandoo Yanner, leader of the Carpentaria Land Council (CLC), the Aboriginal representative body in the region, claims that the high rates of illiteracy in the Gulf meant many Indigenous people were disadvantaged in the negotiations:

Ask the signatories today what is in the agreement today and they can't tell you so that must speak volumes. I am not making fun of them for not reading and writing but if they made a fully informed decision they should at least know in detail some of the agreement. ${ }^{41}$

Employment skills and experience were low, and most employment was through the Community Development Employment Projects (CDEP) scheme, which is a major employer of Aboriginal people in remote Australia. ${ }^{42}$

The region also has a particularly violent history of dispossession, with many documented accounts of settler violence towards Indigenous peoples throughout the early period of colonization. Several authors ${ }^{43}$ have documented the harsh authoritarian missionary practices at Doomadgee, which, together with extreme levels of isolation and deprivation, and a high degree of institutionalization, saw the Aboriginal population of Doomadgee described in a 1950 government report as the "most severely restrained in North Queensland." ${ }^{44}$ While Harwood and Trigger have argued that the Aboriginal people of Doomadgee resisted complete subjugation to white authority ${ }^{45}$ the fact remains that they were among the most institutionalized of all Aboriginal groups in Australia. This was the physical, cultural, social, and economic context within which the Century Zinc negotiations occurred.

The proposal to develop the mine caused tension and disagreement within the Aboriginal communities. For some Aboriginal people in the region, the mine represented the only opportunity to redress the marginalization and poverty that characterized the region's history: "The reality is this mine is going to go ahead whether we like it or not, and if we are not careful we will lose what they have offered us now." 46 For others, it represented another wave of colonialism: "The mining company and the state were acting the same way they did when they came on the first boat." ${ }^{47}$ 
Yanner offered the following assessment of the attitude of the majority of Indigenous people towards the development of the mine:

We were determined to stop them. We didn't want them. We wanted to send them back to England. WE DID NOT WANT THEM. We would be happier without them. That was our first aim and our total aim, to stop them, but we also had a back up plan. Even if we lose we have to lose well because it was a big agreement. But we primarily truly $100 \%$ wanted to wipe them out and not have them here. ${ }^{48}$

At the beginning of negotiations, Aboriginal people in the region had no recognized rights to land under Australian law because the land on which the mineral resource was located, and over which the pipeline would traverse, was pastoral lease. According to the mining company, any consultation undertaken by them was done on the basis of good neighbour relationships, rather than any statutory rights held by the local Aboriginal people. The mining company initiated contact with some Aboriginal groups and communities in 1991, to provide them with information about the proposed project and to seek their cooperation in undertaking the cultural heritage clearances required under Queensland legislation. ${ }^{49}$

At this stage, the mining company was not prepared to consider any proposal for a written agreement with affected Aboriginal people, though it hoped that, by providing information and undertaking consultations, it could obtain their support for the project. ${ }^{50}$ Although the Mabo decision had not been handed down yet, the company proceeded to purchase pastoral leases over the proposed mine site to buffer itself against any future native title claims. ${ }^{51}$ It also commenced a process whereby it chose to consult with some groups over others (notably those groups that were not stridently antimine), privileging these groups throughout the negotiation process. These alleged actions led to a certain level of distrust on the part of the Indigenous people in the region towards the mining company. ${ }^{52}$

According to Yanner, the company's original monetary offer was somewhere in the vicinity of $\$ 100,000$ per year for the life of the mine..$^{53}$ Thus, prior to the Mabo decision, with no statutory obligation to consult with or gain Aboriginal consent, the mining company treated Indigenous 
interests with a certain degree of contempt. The Mabo decision saw a marked change in the mining company's behaviour, which concurred with changes in the global corporate culture of many major mining companies, with mining company executives declaring a commitment to improved community relations with Indigenous peoples. ${ }^{54}$

\section{The Behaviour of the Australian State throughout the Negotiations}

Under the Australian federal system, state governments are responsible for management of land-use issues, and they also issue mineral leases. As Century mine is located in far North West Queensland, the Queensland government had major jurisdictional power in these negotiations. The literature on the historical treatment of Aborigines in Queensland illustrates the denial by successive Queensland governments of any inherent Aboriginal right to land. ${ }^{55}$ The Century negotiations occurred during a period that saw a Labor government elected in Queensland for the first time since 1957. There was great expectation that treatment of Aboriginal interests would change, as the Goss Labor government had been elected on a platform of land rights. However, Holden and Pearson argue that there remained a fundamental ideological opposition within the new Goss Labor government to the idea that Aboriginal people have any inherent right to land. They contend that the Goss government was "essentially racist, suspicious and extremely uncomfortable in its dealings with Aboriginal people." ${ }^{56}$ Thus, a prestructured context existed in Queensland, which had seen Indigenous people historically and institutionally marginalized.

Despite a change of government in Queensland during the negotiations, its approach to the Century project remained constant. Both the Goss Labor government and the Borbidge National/Liberal Coalition government were committed to making the project happen. Wayne Goss, the Labor premier, constantly reiterated his government's commitment to the project in media articles:

There is one thing I would like to do before I leave this job. It is to see a major project like this go ahead...Queensland is about to see its third wave of mining activity...this is the big picture, the stuff dreams are made of. ${ }^{57}$ 
Similarly, when asked if his conservative government supported the development of the mine, Premier Borbidge claimed:

It will be the biggest thing to happen to the northwest of the State and will provide the catalyst for more development throughout the region, which remains one of the last great prospective areas on earth. ${ }^{58}$

A majority of the Indigenous people interviewed agreed that there was no discernible change in the Queensland government's attitude after the election of the Borbidge National/Liberal Coalition government.

Responsibility for the Century project lay with the Office of the Coordinator General (OCG), a powerful economic development agency within the Department of the Premier, Economic Development and Trade (DPEDT). As lead Queensland government agency, the OCG had constant dealings with the mining company. Ian Williams, the manager of the mining company Century Zinc Lead (CZL), offered the following appraisal of OCG's actions: "The person in charge of OCG thought we were being too wimpy and we should just tell them [the Aborigines] to buggar off and get on with the job." 59

Interviewees with senior OCG staff revealed a dominant prodevelopment institutional agenda:

There was a downturn in economic development in the early 1990s and the Goss government was concerned with getting on and doing a lot of economic development of the State. The OCG was quite autonomous and we were just told to get on with doing business. ${ }^{60}$

When asked if there was a strong development agenda within the Goss government, the officer replied "absolutely." ${ }^{11}$ Another senior OCG employee confirmed the government's commitment to development:

Development is jobs and every State government agenda is to keep people happy by providing jobs. ${ }^{62}$

The personal philosophy [of] the leader of OCG, Mr John Down, was to provide jobs at any cost: "I would be prepared to slash and burn to make 
sure that at the end of the day the population had jobs." ${ }^{63}$

In these negotiations, the Queensland government was extremely cautious not to set any legal precedents that might have facilitated the interests of Aboriginal people in future mining negotiations. The Queensland Premier verified the government's desire to avoid setting precedents:

I guess we were cautious because the native title situation was not clear then ...this was a High Court inspired political time bomb, the fuses were still going and we had to weigh that up against getting this project up and running there was certainly a degree of caution no one had been down this road before and we were being careful in terms of precedents. ${ }^{64}$

They also proposed enabling legislation to circumvent the NTA and weaken the native title rights of the Gulf Indigenous communities in order to facilitate speedy development of the mine. It regarded the rights of the Indigenous people in the region as an impediment to mine development, rights that could simply be legislated away.

While major jurisdictional power in the Century negotiations lay with the Queensland government, the Federal government had a large effect on the context within which the negotiations occurred. ${ }^{65}$ The Mabo decision was handed down by the High Court in 1992, affirming that customary rights to land had pre-existed and, in certain places, survived British sovereignty. ${ }^{66}$ The decision overturned the popular belief that Australia was terra nullius at the time of settlement, and confirmed that the common law of England included the doctrine of recognition of native title. ${ }^{67}$ The nature of the title and its implications for the property system of Australia were unclear until the Keating Labor government enacted the Native Title Act (1993). The Act was designed to establish processes by which native title could be recognized and protected, to validate existing non-Indigenous interests in land, and to create a system to accommodate the ongoing grant of title to non-Indigenous interests. It established a compensation regime for those Indigenous people whose native title had been extinguished after $1975,{ }^{68}$ and also established the National Native Title Tribunal (NNTT) to mediate and process native title claims. The Act encountered substantial opposition, particularly from the mining industry, which first sought to 
prevent the introduction of the Act and then lobbied the Commonwealth government to amend the Act, arguing it was unworkable and an impediment to development. ${ }^{69}$

Robert Tickner, minister responsible for Aboriginal affairs within the Keating government, was very much concerned with protecting and safeguarding Aboriginal interests; ${ }^{70}$ however, this position often alienated him within the Federal Labor cabinet, which also had a very prodevelopment agenda. The Keating cabinet had previously supported Northern Territory government legislation to bypass native title legislation to ensure security of title for a major mineral development project: the McArthur River project. ${ }^{71}$ The Federal government's decision to support the NT legislation shattered the confidence and trust that Aboriginal people were developing in the Keating Labor government. ${ }^{72}$

The Federal government under Keating did at times facilitate Indigenous agency through various funding regimes, including funding of the Aboriginal and Torres Strait Islander Council (ATSIC) and Native Title Representative Bodies (NTRBs). After the enactment of the NTA, ATSIC was responsible for administrating and funding Native Title Representative Bodies (NTRBs), which were, in turn, responsible for funding native title claims within their jurisdictions. ${ }^{73}$ Thus, the federal arm of the Australian state, via the federal Office of Indigenous Affairs within the Department of Prime Minister and Cabinet, and eventually ATSIC, provided the funding for representative bodies involved in native title negotiations. They were facilitating Indigenous agency, on one hand, to oppose the mine, while simultaneously pushing a prodevelopment agenda and circumventing Indigenous rights.

There was, however, a definitive change in the role of the Federal arm of the Australian state in the negotiations after the 1996 election of the Howard Liberal coalition government. The Howard government was elected on a platform that included proposals to amend the NTA, so as to reduce the impact of native title on miners and pastoralists. ${ }^{74}$ It continually pointed to the controversy over Century as justification for these amendments, with the Federal Minister for Resources and Energy, Senator Parer, stating that "the government would examine the lessons of Century Zinc and take steps to ensure they did not recur." 75 
As the negotiations stalled and it seemed that an agreement could not be reached, Senator Parer proclaimed:

The failure of these negotiations destroys the arguments of those who maintain the existing negotiations provisions in the Native Title Act work and sends a dangerous message to investors. ${ }^{76}$

Prime Minister Howard continued to threaten amendments to the NTA that would remove any unnecessary impediments to economic development.

In 1997, at the height of the Century negotiations, the Federal government introduced amendments to the NTA in parliament: the Native Title Amendment Bill 1997. Brennan argues that this shows that the government had set a course to wind back any statutory rights granted to native title holders and to withdraw the Commonwealth as far as possible from land management issues, which it wanted returned to the States. ${ }^{77}$ Thus, key Federal legislation - the NTA that had facilitated Indigenous agency and enhanced the Indigenous bargaining position in mineral negotiations-was to be amended. The Native Title Amendment Act 1998 (NTAA), ${ }^{78}$ enacted in 1998 after the Century negotiations, substantially weakened the position of native title claimants and holders. ${ }^{79}$

Other arms of the Australian state, including ATSIC and the National Native Title Tribunal, all played decisive roles in these negotiations. While space precludes discussing each of their roles separately, ${ }^{80}$ ultimately their actions served to facilitate the development of the mine, despite the fact that many Indigenous people in the region had expressed objections. The High Court, however, acted autonomously from the other arms of the state. Several decisions that it handed down throughout the negotiations-in particular the Mabo (1992), Waayni (1995), and Wik (1996) decisionsimproved the bargaining positions of the Indigenous people in the Gulf region, enabling them to eventually reach a substantial $\$ 60$ million agreement with the mining company. While the power of the High Court is vulnerable to the will of the Australian Parliament, and its capacity to judicially intervene is circumscribed by the Australian Constitution, its 
decisions in this case were of major significance, and altered, for a time, the structural context of the negotiations. ${ }^{81}$ However, these decisions could be subject to reversal or diminution by legislative acts of the Parliament, as was the case when the Howard government enacted the Native Title Amendment Act 1998. ${ }^{82,83}$ Russell advocates caution in his assessment of the High Court's capacity to alter the structural context in Australia within which mineral negotiations occur. He argues that however revolutionary the High Court's decisions may have appeared, the changes it effected were always going to depend on how the political system as a whole responded to them. ${ }^{84,85}$

Indigenous Agency Indigenous people were not passive victims throughout the process. Under the leadership of the CLC and Murandoo Yanner, Indigenous people continually exercised their agency, managing to substantially delay the negotiations and see the mining company's original $\$ 100,000$ offer grow into a $\$ 60$ million agreement with substantive employment and environmental conditions. With several significant High Court decisions, particularly the Mabo and Waayni decisions, challenging the fundamental property laws of Australia that underpinned the mineral industry's access to land, there was greater scope for Indigenous people to exercise their agency and shape the outcomes of this particular mineral negotiation to a greater extent than in previous negotiations. Indigenous agency was thus a critical factor in these negotiations. Indeed, a critical finding from this research was the tenacious manner in which Indigenous people continually acted to subvert the actions of the state and the mining company through their own agency. ${ }^{86}$

Before the advent of the Native Title Act 1993, when Indigenous people did not have the right to negotiate, the predominant view in the community was antimine. While this view fluctuated throughout the negotiations, after the enactment of the NTA the view among native title claimants with the right to negotiate was very mixed. Some native title claimants were distinctly in favour of the mine's development. Yet native title claimants who did not want the mine did not have the right to veto, and were unable to prevent development of the mine. The state had historically and insti- 
tutionally marginalized the interests of Indigenous people in mineral development processes, and this resulted in a context that structurally favoured the agency of the state and the mining company and the Indigenous actors who were in favour of the mine going ahead.

Mineral negotiations processes, as prestructured contexts, favour those actors who have greater access to financial and technical resources and access to expertise and information. Both mining companies and the state have access to substantial financial resources. In the Century negotiations, they were able to utilize these extensive resources to coordinate travel over large areas to communicate with Aboriginal people and constantly promote the benefits of the mine to the disparate Aboriginal groups in the region. O'Faircheallaigh argues that Aboriginal people were, and still are, seriously deficient in the financial, organizational, and technical resources required to equitably engage in large-scale resource development negotiations. ${ }^{87}$ Thus, following Archer, the historical distribution of resources and interests laid down structurally over time exerted an important constraining influence on Indigenous agency in this case study of mineral negotiations. ${ }^{88}$

The agency of political actors is also subject to their knowledge of the policy context and the manner in which that context is ideologically constructed. ${ }^{89}$ Knowledge of a context can enhance the capacity for agency, and, in this case, was used by certain Indigenous players in the region to strategically counteract the actions of the state and the mining company. However, this knowledge can be mediated by the prevalence of hegemonic discourses. Hegemonic discourses can contribute to the construction of an ideologically constructed common sense that often favours the options and actions preferred by the other actors. ${ }^{90}$ These discourses can influence the agency of the various actors by mediating their knowledge of the constraints/structures that act upon them. This can be critically important in situations where there are high levels of illiteracy, such as in the Century case. The majority of Indigenous people were not educated and did not have access to knowledge about mineral development-who it privileges, who it marginalizes, and, ultimately, who benefits from it. It could be argued that Indigenous people's capacity to access and interpret the intricacies of a mineral negotiation process was limited. 
The agency of many Indigenous people in the region was constrained by the promulgation of two dominant discourses: a prodevelopment, promining discourse and an anti-Mabo, anti-Aboriginal rights discourse. The hegemonic promining discourse posits development in general, and mining in particular, as a positive thing, good for all citizens and deserving of support and approval. It often resonates with claims of morality and civilization and is deeply infused with European notions of progress and development. ${ }^{91}$ In this discourse, mineral development renders the landscape "productive, civilised, and familiar." 92 Indigenous rights to land, and to participate equitably in mineral developments on those lands, are construed as a direct challenge to national cohesion. ${ }^{93}$

The anti-Mabo, anti-Aboriginal rights discourse similarity posited the Mabo decision as a threat to the nation, and was underpinned by a "sense of disquiet and disbelief that Aborigines have any rights in land which the rest of us must respect." ${ }^{4}$ This discourse evoked fears about security of property rights and future economic development, constituting recognition of Aboriginal rights to land as a direct impediment to future prosperity. Hugh Morgan's contributions are representative of the general tone of this discourse: ${ }^{95}$

The Mabo decision has given substance to the ambitions of communists for a separate Aboriginal state and plunged Australian property law into chaos. ${ }^{96}$

Mabo is a challenge to the legitimacy of Australia. The free, prosperous and dynamic nation that our forbearers built ... is irremediably tainted. ${ }^{97}$

This anti-Mabo discourse was widely promoted in the media, and surveys revealed that a majority of the Australian population believed the Mabo decision constituted a real threat to the security of their property ownership. ${ }^{98}$

The combination of these discursive influences had a significant effect on the final outcomes of the negotiations because they unambiguously favoured the interests of the state and the mining company. Not only was the structured context reinforced by historical and institutional distribution of resources and interests, it was also reinforced by the combination of a promining, prodevelopment discourse and an anti-Mabo, anti-Aboriginal 
rights discourse. This particular structured context was underpinned by an ideology that posited the development of the mine as the legitimate option and the rights of Aboriginal people as an impediment to the legitimate option. Indigenous people's agency was constrained and inhibited by the combination of a historically and institutionally influenced context that favoured the agency of the state and the mining company, and by an ideational construction of mining that favoured those same players. Indigenous actors' capacity to challenge the structural reality of mineral development (their agency) was, in this case, constrained by a combination of structural and discursive factors. The capitalist structural, material, and ideational reality that informed this mineral development context ultimately favoured the agency of the state and the mining company.

In summary, the period during which the Century negotiations occurred (1987-1997) saw significant judicial and legislative changes in relation to Indigenous land rights in Australia. These changes, including the High Court's Mabo 1992 decision and the Native Title Act 1993 (NTA), substantively altered the bargaining power of Indigenous people in relation to mineral developments on their traditional lands, as these decisions challenged the fundamental property laws of Australia that underpinned the mineral industry's access to land. In short, these changes in the structural landscape enhanced their capacity to exercise their agency. Ultimately, however, these major structural changes in Australian political landscape were political decisions that could be, and were, overturned, watered down, or legislated away when the outcomes of that enhanced agency proved unpalatable to the Australian state and the minerals industry. Thus Indigenous agency, though efficacious in this instance, was circumscribed by the historical distribution of resources and interests laid down structurally over time, and by discursive forces that promoted the agency of the other actors in this mineral negotiation process.

Conclusion Following Salee, it has not been the aim of this paper to downplay or underestimate Indigenous agency's capacity to transform unequal relationships of power. ${ }^{99}$ Quite the contrary, it was a distinctive finding from previous research that Indigenous agency matters. ${ }^{100}$ Examples 
of the transformative capacity of Indigenous agency abound and, in the Australian case, the agency of Eddie Mabo and those that challenged the judicial settlement of Australia, and succeeded in overturning the doctrine of terra nullius that underpinned the colonization of Aboriginal Australia, is an exemplar of the transformative capacity of Indigenous agency. The aim of this paper has been to call for a degree of caution when celebrating the transformative capacity of this agency. Given the structured political reality within which Indigenous people must operate, their objective reality, it seemed prescient to revisit the debate on structure and agency via a case study of mineral negotiations involving Indigenous people, and to highlight the constraining and inhibiting power that structure can exert over agents' capacity to exercise their agency. In essence, structure can inhibit or constrain the capacity for actors to actively change or ameliorate their objective reality. While the relationship between structure and agency may indeed be dialectical, it is also a temporal relationship-agency is always expressed within contexts that are provided by a pre-existing set of social structures. In this instance, the historical relationship between the state and the mining company provided a prestructured context that constrained and inhibited the agency of the Indigenous actors.

There can be no doubt that agency matters and has transformative capacity. Overstating the transformative capacity of agency, however, may result in a lack of analytical and theoretical interrogation of the forces and structural realities that can, and do, constrain and inhibit Indigenous agency. Indigenous people will take every opportunity to exercise their agency, and, thus, knowledge of the structural constraints that may impinge upon the exercise of that agency is essential, and must be disseminated in academic literature and analysis. 


\section{Notes}

This paper was first presented at the Canadian Political Science Conference in Ottawa (May 2008). I would like to thank Peter Irving and Monica Seini for their helpful comments on an earlier version of the full paper. This research was undertaken, in part, thanks to funding from the Centre for Governance and Public Policy, Griffith University, Australia, which also provided funding to attend the conference where this paper was first presented.

1. E. Laclau and C. Mouffe, Hegemony and Socialist Strategy. Towards a Radical Democratic Politics $2^{\text {nd }}$ ed. (London: Verso, 2001), p. xvi.

2. J.A. McNeish and R. Eversole, "Introduction," in R. Eversole, J.A. McNeish, and A. Cimadamore, (eds.), Indigenous Peoples and Poverty, An International Perspective (London: Zed Books, 2005), p. 2.

3. T. Fournier, "Preface," in B. Hocking, (ed.), Unfinished Constitutional Business? Rethinking Indigenous Self-determination (Canberra: Aboriginal Studies Press, 2005), p. vii.

4. J. Render, Mining and Indigenous Peoples Issues Review (London: International Council of Mining and Metals (ICMM), 2005) (accessed 6 June 2005).

5. See D. Trigger, "Mining Projects in Remote Australia: Sites for the Articulation and Contesting of Economic and Cultural Futures," in D. Austin-Broos and G. Macdonal, (eds.), Culture, Economy and Governance in Aboriginal Australia (Sydney: Sydney University Press, 2005), p. 42.

6. C. O'Faircheallaigh, Creating Opportunities for Positive Engagement: Aboriginal People, Government and Resource Development in Australia (Brisbane, Australia: International Conference on Engaging Communities, 2005), p. 2.

7. C. O'Faircheallaigh, Negotiating a Better Deal for Indigenous Land Owners: Blending "Research" and "Community Service" Public Lecture Series 2000 (Brisbane: Griffith University); R. Howitt, Rethinking Resource Management. Justice, Sustainability and Indigenous Peoples (London: Routledge, 2001); N. Pearson, "Land Is Susceptible of Ownership," in M. Langton, M. Tehan, L. Palmer, and K. Shain, (eds.), Honour Among Nations? Treaties and Agreements with Indigenous People (Melbourne: Melbourne University Press, 2004).

8. Howitt, Rethinking Resource Management, p. 143.

9. S. Bell, Economic Governance and Institutional Dynamics (Melbourne: Oxford University Press, 2002), p. 2.

10. R. Howitt, Rethinking Resource Management, p. 139.

11. Colin Hay, "Introduction," in C. Hay, M. Lister, and D. Marsh, (eds.), The State: Theories and Issues (Hampshire, UK: Palgrave McMillan, 2006), p. 11.

12. R. Howitt, J, Connell, and P. Hirsh, (eds.), Resources Nations and Indigenous Peoples. Case Studies from Australasia, Melanesia and Southeast Asia (Oxford: Oxford University Press, 1996), p. 14.

13. See, for example, J.P. Roberts, Massacres to Mining: The Colonisation of Aboriginal Australia (Melbourne: Dove Communications, 1981); A. Chase, "Anthropology and Impact Assessment: Development Pressures and Indigenous Interests in Australia," Environmental Impact Assessment Review 10/1 \& 2 (1990), pp. 11-25; M. Lane, Land Use, Development and Social Impact on Cape York Peninsula NARU Discussion Paper 21 (Darwin: Northern Australia Research Unit, 1993); M. Lane and A. Chase, "Resource Development on Cape York Peninsula: Marginalisation and Denial of Indigenous Perspectives," in Howitt, Connell, and Hirsch, Resources Nations and Indigenous Peoples: R.A. Dixon and M. Dillon, (eds), Aborigines and Diamond Mining, The Politics of Resource Development in the East Kimberley Western Australia (Nedlands: University of Western Australia, 1990); S. Hawke and M. Gallagher, Noonkanbah, Whose Land, Whose Law (Fremantle: Fremantle Arts Centre, 1989); R. Howitt, Rethinking Resource Management, E. Harman, and B. Head, State Capital and Resources in the North and West of Australia (Nedlands: University of Western Australia Press, 1981); C. O'Faircheallaigh, "Mining," in B. Galligan, O. Hughes, and C. Walsh, (eds.), Intergovernmental Relations and Public Policy (Sydney: Allen, and Unwin, 1991); C. O’Faircheallaigh, "Resource Development and Inequality in Indigenous Societies," CAPSM Research Paper No. 2 (Brisbane: Centre for 
Australian Public Sector Management, Griffith University, 1996); C. O’Faircheallaigh, "Overcoming Severe Obstacles to Public Participation: Indigenous People and Impact Assessment Procedures in Australia," in P. McLaverty, (ed.), Public Participation and Innovations in Community Governance (London: Ashgate, 2002); C. O'Faircheallaigh, Creating Opportunities for Positive Engagement: Aboriginal People, Government and Resource Development in Australia International Conference on Engaging Communities (Brisbane, Australia: 14-17 August 2005); C. O'Faircheallaigh, "Aborigines, Mining Companies and the State in Contemporary Australia: A New Political Economy or 'Business as Usual'?" Australian Journal of Political Science 41/1 (2006), pp. 1-22; S. Cowell, "Aboriginal Interests and the Century Zinc Proposal: Resource Planning, Development and Impact Assessment in the Gulf of Carpentaria" (Honours Dissertation, Faculty of Environmental Sciences, Brisbane, Griffith University, 1996).

14. Render, Mining and Indigenous Peoples Issues Review.

15. J. Connell and R. Howitt, Mining and Indigenous Peoples in Australasia (Sydney: Sydney University Press, 1991), pp.4-7.

16. See, for example, M. Lane and S, Cowell, "Land and Resource Planning and Indigenous Interests," in O. Yiftachel, J. Little, D. Hedgcock, and I. Alexander, (eds.), The Power of Planning: Spaces of Control and Transformation (Dordrecht: Kluwer, 2001); A. Harwood, "Indigenous Sovereignty and Century Zinc," in G. Evans, J. Goodman, and N. Lansbury, (eds.), Moving Mountains Communities Confront Mining and Globalisation (London: Zed Books, 2002); M. Blaser, H. Feit, and G. McRae, (eds.), In the Way of Development. Indigenous Peoples, Life Projects and Globalization (London: Zed Books, 2004); K. Trebeck, "Tools for the Disempowered? Indigenous Leverage Over Mining Companies," Australian Journal of Political Science 42/4 (2007), pp. 541-562; D. Salee, "James Bay Cree (Eeyou Eenou) and Natural Resources Management: Perspectives on the Political Agency of Indigenous Peoples in Canada," Paper Presented to the Annual Conference of the Canadian Political Science association (Vancouver, BC: University of British Columbia, 4-6 June 2008).

17. S. McAnnulla, "Structure and Agency," in D. Marsh and G. Stoker, (eds.), Theory and Methods in Political Science $2^{\text {nd }}$ ed. (Hampshire, UK: Palgrave Macmillan, 2002), p. 271.

18. S. McAnnulla, "Structure and Agency," pp. 93-94.

19. C. Hay, Political Analysis, A Critical Introduction (Hampshire: Palgrave, 2002).

20. P.A. Lewis, "Agency, Structure and Causality in Political Science. A Comment on Sibeon," Politics 22/1 (2002), pp.17-18.

21. See, for example, R. Sibeon, "Agency, Structure, and Social Chance as Cross-Disciplinary Concepts," Politics 19/3 (1999), pp. 139-144; M. Archer, "For Structure: Its Reality, Properties and Powers: A Reply to Anthony King," Sociological Review 48/3 (2000), pp. 464-472; C. Hay, Political Analysis, A Critical Introduction; S. McAnulla, Theory and Methods in Political Science.

22. C. Hay, Political Analysis, A Critical Introduction, p. 94.

23. R. Sibeon, "Agency, Structure, and Social Chance as Cross-Disciplinary Concepts," Politics (1999), p. 142.

24. C. Hay, Political Analysis, A Critical Introduction, p. 94.

25. S. McAnnulla, Theory and Methods in Political Science, p. 271; C. Hay, Political Analysis, A Critical Introduction, p. 94.

26. C. Hay, Political Analysis, A Critical Introduction, pp. 95-97.

27. W. Legget, "Social Change, Values and Political Agency: The Case of the Third Way," Politics 24/1(2004), pp. 12-19.

28. A. Giddens, Central Problems in Social Theory London: Macmillan, 1979); A. Giddens, The Constitution of Society (Cambridge: Polity Press, 1984); A. Giddens, "Elements of the Theory of Structuration," in A. Elliot, (ed.), Contemporary Social Theory (Oxford: Blackwell, 1999).

29. Cited in C. Hay, Political Analysis, A Critical Introduction, p. 118; S. McAnnulla, Theory and Methods in Political Science, p. 33.

30. R. Sibeon, Politics, p. 139.

31. C. Hay, Political Analysis, A Critical Introduction, p. 127. 
32. M. Archer, Sociological Review.

33. M. Archer, Sociological Review, pp. 463-465; S. McAnnulla, Theory and Methods in Political Science.

34. P. A. Lewis, Politics, p. 19.

35. C. O'Faircheallaigh, Creating Opportunities for Positive Engagement: Aboriginal People, Government and Resource Development in Australia.

36. Ibid.

37. Interview: R. Borbidge, Former Queensland Premier (Brisbane, Queensland: 27 April 2004).

38. D. E. Smith and J. Altman, "Lessons from Century: ATSIC and the Right to Negotiate over Major Resource Development Projects," Report to Native Title and Land Rights Branch (Canberra: Aboriginal and Torres Strait Islander Commission, Smith and Altman, 1998), p. 7.

39. G. Crough and D. Cronin, "Aboriginal People and the Century Project: The 'Plains of Promise' Revisited?" A Report to the CLC, Burketown, commissioned by Century Zinc Limited through Kinhill Cameron McNamara (Darwin: NARU, 1995).

40. G. Crough and D. Cronin, "Aboriginal People and the Century Project: The 'Plains of Promise' Revisited", p. 10; D. E. Smith and J. Altman, "Lessons from Century: ATSIC and the Right to Negotiate over Major Resource Development Projects," p. 1.

41. Interview: M. Yanner, Former Manager of Carpentaria Land Council (Burketown, Queensland: 7 March 2005).

42. D. E. Smith and J. Altman, "Lessons from Century: ATSIC and the Right to Negotiate over Major Resource Development Projects," p. 7; D. Martin, "Deal of the Century? A Case Study from the Pasminco Century Project," Indigenous Law Bulletin 4/11 (1998), pp. 4-18.

43. See D. Trigger, Whitefella Comin': Aboriginal Responses to Colonialism in Northern Australia (Melbourne: Cambridge University Press, 1992); S. Cowell, Aboriginal Interests and the Century Zinc Proposal: Resource Planning, Development and Impact Assessment in the Gulf of Carpentaria; A. Harwood, Moving Mountains Communities Confront Mining and Globalisation; T. Roberts, Frontier Justice. A History of the Gulf Country to 1900 (St Lucia: University of Queensland Press, 2005).

44. Cited in D. Trigger, Whitefella Comin': Aboriginal Responses to Colonialism in Northern Australia, p. 71.

45. A. Harwood, Moving Mountains Communities Confront Mining and Globalisation; D. Trigger, Whitefella Comin': Aboriginal Responses to Colonialism in Northern Australia.

46. Anonymous, "Mine Not Dead," North West Country 8/70 (1997).

47. Interview: M. Yanner.

48. Interview: M. Yanner.

49. Cowell, Aboriginal Interests and the Century Zinc Proposal.

50. R. Blowes and D. Trigger, "Negotiating the Century Mine Agreement: Issues of Law, Culture and Politics," in M. Edmunds, (ed.), Regional Agreements in Australia: Vol 2: Case Studies (Canberra: Australian Institute for Aboriginal and Torres Strait Islander Studies (AIATSIS), 1999).

51. P. Wear, "Problems in the Pipeline," The Bulletin (14 May 1996).

52. S. Cowell, Aboriginal Interests and the Century Zinc Proposal, p. 81.

53. Interview: M. Yanner.

54. F. Brennan, The Wik Debate: Its Impact on Aborigines, Pastoralists and Miners (Sydney: UNSW Press, 1998), p. 22; R. Howitt, Rethinking Resource Management, p. 261.

55. See, for example, R. Kidd, The Way We Civilise: Aboriginal Affairs The Untold Story (St Lucia: University of Queensland Press, 1997); J.P. Roberts, Massacres to Mining: the Colonisation of Aboriginal Australia; M. Lane, Land Use, Development and Social Impact on Cape York Peninsula; R. Howitt, Rethinking Resource Management.

56. A. Holden and N. Pearson, "Time for Leadership: Issues of Importance to Aboriginal and Islander People," in B. Stevens and J. Wanna, (eds.), The Goss Government. Promise and Performance of Labour in Queensland (Melbourne: Macmillan Education Australia Pty Ltd, 1993), p. 194.

57. P. Morley, "Goss Tips Third Mining Boom," Courier Mail (9 November 1995). 
58. S. Emerson and D. Fagan, “\$30m Native Title Deal Opens the Door to Century Mine," The Australian (8 May 1997).

59. Interview: I. Williams, Former CEO of Century Zinc Limited (Perth, Western Australia: 20 April 2004 and 21 April 2004).

60. Interview: R. Potter, Former Officer, OCG, DEPTD, Queensland Government (Brisbane, Queensland: 9 July 2004).

61. Ibid.

62. Interview: I. Clague, Former Officer, OCG, DEPTD, Queensland Government (Brisbane, Queensland: 9 July 2004).

63. P. Gillepsie, "New Power Broker is a Quiet Achiever," Sunday Mail (9 May 1993).

64. Interview: R. Borbidge, Former Queensland Premier (Brisbane, Queensland: 27 April 2004).

65. C. O'Faircheallaigh, Australian Journal of Political Science, p. 10.

66. M. Langton, M, Tehan, L. Palmer, and K. Shain, (eds.), Honour Among Nations. Treaties and Agreements with Indigenous People (Melbourne: Melbourne University Press, 2004) p. 17.

67. N. Pearson, "Land is Susceptible of Ownership," in M. Langton, M. Tehan, L. Palmer, and K. Shain, (eds.), Honour Among Nations? Treaties and Agreements with Indigenous People (Melbourne: Melbourne University Press, 2004), p. 84.

68. In 1975, the Racial Discrimination Act was passed, meaning that all Australians needed to be treated similarly in all matters including compensation for loss of property under the Constitution.

69. J. Healy, (ed.), "Aboriginal Land Rights," Issues in Society 169 (Rozelle, New South Wales: The Spinney Press, 2002), p. 15.

70. Interview: H. Wootten, Former Federal Government Appointment Chief Negotiator (Tea Gardens, New South Wales, 21 April 2005).

71. The Northern Territory government enacted special legislation for the McArthur River mine a $\$ 250$ million zinc-silver-lead mine to ensure security of title for the project proponents. In effect, the legislation suspended the native title rights of the Indigenous people in the region.

72. R. Tickner, Taking a Stand: Land Rights to Reconciliation (Crows Nest; Allen \& Unwin, 2001), p. 106.

73. D. E. Smith and J. Altman, "Lessons from Century: ATSIC and the Right to Negotiate over Major Resource Development Projects."

74. R. Bartlett, "Is Equality too Hard for Australia?" University of New South Wales Law Journal 20/2 (1997), pp. 492-494.

75. Cited in B. Burton, "CRA's Century Debacle," Mining Monitor 1/2 (2 September 1996).

76. Anonymous, "Mine Not Dead," North West Country 8/70 (February 1997).

77. F. Brennan, The Wik Debate: Its Impact on Aborigines, Pastoralists and Miners (1998), p. 37.

78. The act received widespread condemnation, both at home and abroad, for compromising Indigenous rights. See J. Altman and T. Rowse, "Indigenous Affairs," in P. Saunders and J. Walter, (eds.), Ideas and Influence. Social Science and Public Policy in Australia (Sydney: University of New South Wales Press, 2005). Australia was brought into international disrepute and asked to explain its changes to the Native Title Act to the United Nations Committee for the Elimination of Racial Discrimination (CERD). Australia is the first western nation asked to explain its human rights position to the committee; J. Healy, (ed.), "Aboriginal Land Rights," Issues in Society (2002).

79. C. O'Faircheallaigh, Creating Opportunities for Positive Engagement: Aboriginal People, Government and Resource Development in Australia, p.10.

80. For more detail, see C. Howlett, "Indigenous People and Mining: The Role of the State. A Case Study of Century Zinc Mine," Unpublished PhD Thesis (Brisbane, Australia: Griffith University, 2007).

81. M. Bachelard, The Great Land Grab: What Every Australian Should Know About Wik, Mabo and the Ten-point Plan (South Melbourne: Hyland House, 1997), p.71.

82. H. Patapan, Judging Democracy (Oakleigh: Cambridge University Press, 2003), p. 112.

83. It is worth pointing out that the Howard Government suspended the RDA, and the protection it afforded Indigenous people's rights, when it enacted the NTAA in 1998, claiming the 
Act was a "special measure." See M. Widdowson-Kidd, "The Howard Government's Special Measures for Indigenous Australians," Queensland Law Student Review 1/2 (2008), pp.117-130.

84. P.H. Russell, Recognizing Aboriginal Title. The Mabo Case and Indigenous Resistance to English Settler Colonialism (Toronto: University of Toronto Press, 2005), p. 5.

85. The Australian parliament can also politicize the High Court via the appointment of new judges. The Howard government appointed conservative judges, believing this would redress the fact that the High Court had been too reformist in the Mabo judgment. (For further discussion, see Howlett, “Indigenous People and Mining," pp. 177-183).

86. For further elaboration, see Ibid.

87. C. O'Faircheallaigh, Australian Journal of Political Science, p. 4.

88. M. Archer, Sociological Review.

89. C. Hay, Political Analysis, A Critical Introduction, p.132.

90. S. McAnnulla, Theory and Methods in Political Science, p. 285.

91. D. Trigger, "Citizenship and Indigenous Responses to Mining in the Gulf Country," in N. Peterson and W. Sanders, (eds.), Citizenship and Indigenous Australians: Changing Conceptions and Possibilities (Melbourne: Cambridge University Press, 1998); A. Escobar, Encountering Development in Theory and Practice: Paradigms and Paradoxes $2^{\text {nd }}$ ed. (Boulder: Westview Press, 1995).

92. D. Trigger, "Mining, Landscape and the Culture of Development Ideology in Australia," Ecumene 4/2 (1997), pp. 166.

93. R. Howitt, J. Connell, P. Hirsh, Resources Nations and Indigenous Peoples. Case Studies from Australasia, Melanesia and Southeast Asia (Oxford: Oxford University Press, 1996), p.14.

94. G. Cowlishaw, "Did the Earth Move for You?: The Anti Mabo Debate," Australian Journal of Anthropology 6/1 (1995), p. 45.

95. Hugh Morgan was executive director of Western Mining Company. Russell claims he was by far the fiercest and loudest critic of the Mabo decision. P.H. Russell, Recognizing Aboriginal Title. The Mabo Case and Indigenous Resistance to English Settler Colonialism, p. 282.

96. Cited in N. Sharp, No Ordinary Judgement: Mabo, The Murray Islanders' Land Case (Canberra: Aborigines Studies Press, 1996), p. 217.

97. Cited in P.H. Russell, Recognizing Aboriginal Title. The Mabo Case and Indigenous Resistance to English Settler Colonialism, p. 283.

98. M. Goot, "The Wild West? Yes, No and Maybe," in M. Goot and T. Rowse, (eds.), Make a Better Offer. The Politics of Mabo (Leichhardt, Pluto Press, 1994).

99. D. Salee, James Bay Cree (Eeyou Eenou) and Natural Resources Management: Perspectives on the Political Agency of Indigenous Peoples in Canada (2008).

100. C. Howlett, "Indigenous People and Mining." 